\title{
PENERAPAN MODEL VCT (VALUE CLARIFICATION TECHNIQUE) DENGAN MENGGUNAKAN MEDIA CERITA DAERAH DALAM PEMBELAJARAN PENDIDIKAN KEWARGANEGARAAN UNTUK MENINGKATKAN KARAKTER PESERTA DIDIK
}

\author{
Vety Fitriani, Dadang Sundawa \\ Departemen Pendidikan Kewarganegaraan, SPs, UPI, email: vety_fitriani@yahoo.com
}

\begin{abstract}
Research is moving on from the issue of the behavior of learners wich displays the attitude that is not commendable, be less attention and enthusiastic in the learning process so that those conditions concern the researcher to know in depth about the importance of the creation of the character of learners. The approach used is the qualitative approach witj action research methods class. Based on the findings of there search result in the field through instruments of direct observation or interviews that the character formation learners positively impact the learning effectiveness againt $P K n$ teachers can identify the behavior of learners, learns can analyse and disclose his opinion regarding media story area, learners understand the material presented by the teacher in the classroom. The VCT model affect the appearance of religiosity attitudes, honesty, intelligence, toughness, concern, democracy.
\end{abstract}

Keywords: Model VCT, media local story, character.

\section{PENDAHULUAN}

Pembelajaran Pendidikan Kewarganegaraan (PKn) di SMP Negeri 1 Kersamanah belum berlangsung optimal. Umumnya peserta didik di sekolah ini masih menganggap pelajaran PKn sebagai pelajaran kurang penting jika di bandingkan pelajaran lain, terutama dibandingkan dengan pelajaran yang diujikan dalam Ujian Nasional. PKn dipandang sebagai pelajaran tidak menarik bahkan membosankan yang disampaikan oleh guru dengan hanya menggunakan ceramah. Berbagai persoalan tersebut menyebabkan guru yang akan dijadikan sebagai kolaborator dalam penelitian ini melakukan inovasi dengan mengembangkan pembelajaran PKn baik dalam variasi model pembelajaran maupun penggunaan media. Selain itu, penelitian inipun beranjak dari masalah perilaku peserta didik yang menampilkan sikap tidak terpuji, berupa kurang perhatian dan antusias dalam proses pembelajaran sehingga menjadi keprihatinan peneliti untuk mengetahui secara mendalam tentang pentingnya pemben-tukan karakter peserta didik dalam proses pembelajaran PKn.
Tujuan mengajar di kelas yang dilakukan oleh guru bukanlah semata-mata transformasi pengetahuan, namun sebagai upaya pendidikan yang berusaha menghasilkan manusia seutuhnya tidak hanya secara kognitif saja melainkan dalam hal afektif dan psikomotornya. Hal ini senada dengan UU RI tentang Sisdiknas No. 20 Tahun 2003 Pasal 3 dijelaskan bahwa:

Mengembangkan kemampuan dan membentuk karakter serta peradaban bangsa yang bermartabat dalam rangka mencerdaskan kehidupan bangsa. Pendidikan nasional bertujuan untuk berkembangnya potensi peserta didik agar menjadi manusia yang beriman dan bertakwa kepada Tuhan Yang Maha Esa, berakhlak mulia, sehat, berilmu, cakap, kreatif, mandiri, dan menjadi warga negara yang demokratis serta bertanggung jawab.

Menurut Daryono (2008, hlm. 13) mengemukakan bahwa tujuan pendidikan di atas mengindikasikan bahwa secara umum sasaran pelaksanaan pendidikan adalah terciptanya sumberdaya manusia yang berkualitas dan berdaya saing. Selain itu agar pendidikan tidak hanya membentuk insan Indonesia yang cerdas, namun juga berkepribadian atau berkarakter, 
sehingga nantinya akan lahir generasi bangsa yang tumbuh berkembang dengan karakter yang bernafas nilai-nilai luhur bangsa serta agama. Tujuan Pendidikan Kewarganegaraan adalah mewujudkan karakter warga negara ideal, yaitu warga negara yang memiliki semangat kebangsaan, cinta tanah air, demokratis, dan bertanggung jawab.

Djahiri (2006, hlm. 9) mengemukakan bahwa "Pendidikan Kewarganegaraan merupakan program pembelajaran yang secara programatik-prosedural berupaya memanusiakan (humanizing) dan membudayakan (civilizing) serta memberdayakan peserta didik (diri dan kehidupannya) supaya menjadi warga negara yang baik sebagaimana tuntutan keharusan/yuridis konstitusional bangsa/negara yang bersangkutan". Sejalan dengan itu, Koesoma (2009, hlm. 204) menyatakan bahwa:

...karakter lebih dekat maknanya dengan pendidikan kewarganegaraan, sebab karakter berurusan bukan hanya dengan pembangunan nilai-nilai moral dalam diri individu, melainkan juga memperhatikan corak rasional antar individu dalam relasinya dengan struktur sosial yang ada dalam masyarakatnya. Untuk itu karakter tidak bisa lepas dari semangat untuk mendidik setiap warga negara secara politis, sehingga pendidikan kewarganegaraan menjadi bagian yang tak terpisahkan dengan pendidikan karakter.

PKn sudah menjadi bagian inheren dari instrumentasi serta praksis pendidikan nasional untuk mencerdaskan kehidupan bangsa Indonesia melalui koridor "value-based education". Konfigurasi atau kerangka sistematik PKn dibangun atas dasar paradigma sebagai berikut:

Pertama, PKn secara kurikuler dirancang sebagai subjek pembelajaran yang bertujuan untuk mengembangkan potensi individu agar menjadi warga negara Indonesia yang berakhlak mulia, cerdas, partisipatif, dan beratanggung jawab. Kedua, PKn secara teoretik dirancang sebagai subjek pembelajaran yang memuat dimensi-dimensi kognitif, afektif, dan psikomotorik yang bersifat konfluen atau saling berpenetrasi dan terintegrasi dalam konteks substansi ide, nilai, konsep, dan moral pancasila, kewarganegaraan yang demokratis, dan bela negara. Ketiga, PKn secara programatik dirancang sebagai subjek pembelajaran yang menekankan pada isi yang mengusung nilainilai (content-embedding values) dan pengalaman belajar (learning experiences) dalam bentuk berbagai perilaku yang perlu diwujudkan dalam kehidupan sehari-hari dan merupakan tuntunan hidup bagi warga negara dalam kehidupan bermasyarakat, berbangsa, dan bernegara sebagai penjabaran lebih lanjut dari ide, nilai, konsep, dan moral pancasila, kewarganegaraan yang demokratis, dan bela negara. (Budimansyah, 2008, hlm. 180; Winataputra \& Budimansyah, 2007, hlm. 86)

Rokeah (dalam Darmadi, 2009, hlm. 27) menyatakan bahwa nilai merupakan sesuatu yang berharga, dan dianggap bernilai, adil, baik dan indah serta menjadi pedoman atau pegangan diri. Hal ini sejalan dengan pandangan Rokeah ialah Sapriya (2011, hlm. 53) yang menyatakan bahwa pada hakikatnya nilai merupakan sesuatu yang sangat berharga, nilai adalah seperangkat keyakinan atau prinsip perilaku yang telah mempribadi dalam diri seseorang atau kelompok masyarakat tertentu yang terungkap ketika berpikir atau bertindak. Kedua ahli di atas mengungkapkan bahwa nilai merupakan sesuatu yang sangat penting bagi setiap orang. Nilai menjadi patokan dan dasar bagi setiap orang dalam mengambil keputusan dan berperilaku kesehariannya. Maka pendidikan nilai mutlak, harus diberikan kepada peserta didik dalam setiap proses pembelajaran.

Nilai-nilai karakter Said (2010, hlm. 9) bahan pelatihan penguatan metodologi pembelajaran berdasarkan nilai budaya untuk membentuk daya saing dan karakter bangsa, pengembangan pendidikan budaya dan karakter bangsa menyebutkan ada 18 nilai-nilai karakter yaitu religius, jujur, toleransi, disiplin, kerja keras, kreatif, mandiri, demokratis, rasa ingin tahu, semangat kebangsaan, cinta tanah air, 
menghargai prestasi, bersahabat/komunikatif, cinta damai, gemar membaca, peduli lingkungan, peduli sosial, tanggung jawab. Nilainilai pangkal tolak pengembangan karakter Direktorat PSMP ada 6 adalah religiusitas, kejujuran, kecerdasan, ketangguhan, kepedulian, demokrasi. Nilai-nilai karakter akan diterapkan dalam proses pembelajaran di kelas melalui penanaman nilai-nilai.

Nilai-nilai karakter bukan sekedar memiliki dimensi integratif, dalam arti mengukuhkan moral intelektual anak didik sehingga menjadi pribadi yang kokoh dan tahan uji. Pendidikan karakter menjadi sebuah jalan keluar bagi proses perbaikan. Situasi sosial yang ada menjadi alasan utama agar pendidikan karakter segera dilaksanakan dalam lembaga pendidikan. Karena itulah menarik untuk mempertanyakan dan menelusuri sejauhmana sekolah sebagai lembaga pendidikan formal menjalankan pendidikan karakter melalui proses pembelajaran di kelas.

Berkenaan dengan hal tersebut sejalan dengan pendapat Winarno (2013, hlm. 219) PKn merupakan kelompok mata pelajaran kewarganegaraan dan kepribadian yang dimaksudkan untuk pening-katan kesadaran dan wawasan peserta didik akan status, hak, dan kewajibannya dalam kehidupan bermasyarakat, berbangsa, dan bernegara serta peningkatan kualitas dirinya sebagai manusia.

Hal ini sejalan dengan Djahiri (1985, hlm. 54) Model VCT peserta didik diajarkan untuk, sebagai berikut : 1) Memberikan nilai atas sesuatu; 2) Membuat penilaian yang rasional dan dapat dipertanggungjawabkan; 3) Memiliki kemampuan serta kecenderungan untuk mengambil keputusan yang menyangkut masalah nilai dengan jelas, rasional, dan objektif; 4) Memahami dan mengamalkan nilai-nilai yang berlaku di dalam masyarakat.

Menurut Dajahiri (1985, hlm. 67) model pembelajaran VCT meliputi: metode percontohan, analisis nilai, daftar/matriks, kartu keyakinan, wawancara, yurisprudensi dan teknik inkuiri nilai. Model di atas dianggap sangat cocok diterapkan dalam pembelajaran PKn, karena mata pelajaran PKn mengemban misi untuk membina nilai, moral, sikap, dan perilaku peserta didik, disamping membina kecerdasan (knowledge) bagi peserta didik.

Penerapan model VCT menggunakan media cerita daerah, kenapa yang dipilih model VCT dan media cerita daerah hal ini berdasarkan pengamatan yang telah peneliti lakukan di kelas VIII-F SMP Negeri 1 Kersamanah Garut dalam pembelajaran PKn, ditemukan bahwa harus adanya penanaman nilai-nilai karakter dalam proses pembelajaran dengan model VCT menggunakan media cerita daerah, peserta didik dapat mempraktekkan dalam kehidupan sehari-hari seperti nilai-nilai karakter religiusitas, kejujuran, kecerdasan, ketangguhan, kepedulian, demokrasi. selain itu setelah mengamati proses pembelajaran ternyata adanya keterbatasan dalam penggunaan fasilitas. Keterbatasan penggunaan fasilitas tersebut cukup menyulitkan guru dalam menyampaikan materi pelajaran PKn yang sangat luas ini, sehingga menjadi kendala terhadap jalannya pembelajaran. Untuk memberikan pembelajaran yang sejalan dengan pemahaman peserta didik, maka guru harus menyajikan materi baik secara verbal maupun secara visual. Tentunya dengan menggunakan media cerita daerah dapat mempermudah pembelajaran, dengan PKn tingkat ketercapaian standar kriteria ketuntasan minimal (KKM) yaitu dengan nilai 75 .

Guru menggunakan strategi mengajar sederhana yang dimiliki. Seharusnya guru sebagai fasilitator sangat memiliki peran dalam mengorganisasikan pembelajaran agar lebih bermakna dan menyenangkan. Dalam prateknya guru PKn terjebak dengan pola-pola pembelajaran konvesional yang didominasi oleh metode ceramah dan tanya jawab di kelas dengan buku sebagai sumber utamanya. Proses belajar cenderung hanya menetapkan 
pendekatan yang kurang memberikan kesempatan kepada peserta didik untuk belajar aktif dan mandiri. Selain itu tujuan pembelajaran hanya berorientasi pada pengembangan aspek kognitif, sehingga mata pelajaran PKn dianggap mata pelajaran hapalan belaka yang membosankan dan kurang bermanfaat dalam kehidupannya. Hal ini sejalan menurut Komalasari (2011, hlm. 8) melihat bahwa kondisi pembelajaran PKn selama ini ternyata masih didominasi oleh sistem konvensional, sehingga pembelajaran yang berorientasi pada konsep "contextualized multiple intelegence" masih jauh dari harapan.

Al Muchtar (2008) juga, menyatakan bahwa kelemahan pembelajaran PKn selama ini yaitu kegiatan berpusat pada guru (teacher center), orientasi pada hasil lebih kuat, kurang menekankan pada proses, posisi peserta didik dalam kondisi pasif siap menerima pelajaran, pengetahuan lebih kuat daripada sikap dan keterampilan, berpikir kognitif rendah, penggunaan metode terbatas, situasi pembelajaran tidak menyenangkan, satu arah-indoktrinasi. Kondisi seperti ini, maka harapan untuk membentuk warga negara yang berkarakter masih sulit terwujud.

Dengan demikian, yang telah di ungkapkan di atas guru lebih banyak menggunakan metode ceramah dalam menyampaikan materi pembelajaran dan memberikan tugas-tugas. Hal ini dirasa ampuh untuk menggantikan pembelajaran tanpa menggunakan media pembelajaran, walaupun terlihat sebagian antusias peserta didik dalam mengikuti pembelajaran. Kelemahan pembelajaran serta terbatasnya penggunaan fasilitas tersebut, perlu diimbangi dengan pemanfaatan-pemanfaatan media pembelajaran yang lebih menarik seperti menggunakan media sederhana yang mudah diperoleh dalam penggunaannya, seperti dengan menggunakan media cerita daerah.

Diikutsertakannya cerita daerah dalam pembelajaran model VCT, maka secara tidak disadari peserta didik mulai berlatih menganalisis nilai-nilai karakter yang ada di dalam cerita daerah tersebut dalam memahami materi pembelajaran PKn serta dapat mengaitkannya dan mempraktekkan pada kehidupan sehari-hari. Praktisnya peserta didik dapat memberikan komentar terhadap media cerita dan memahami nilai-nilai karakter yang terkandung dalam cerita daerah. Pada mata pelajaran PKn sendiri model VCT ini sangatlah diperlukan.

Sejalan dengan Wahab \& Sapriya (2011, hlm. 336) mengemukakan tujuan PKn agar dapat membangun peserta didik sebagai warga negara yang baik dan cerdas secara intelektual, emosional, sosial, spiritual, bertanggung jawab dan mampu berpartisipasi dalam kegiatan bermasyarakat, berbangsa dan bernegara." Media cerita daerah ini dapat membangkitkan motivasi peserta didik untuk memahami nilainilai karakter yang terkandung dalam cerita daerah, Arsyad (2011, hlm. 20) mengungkapkan bahwa "Media pembelajaran juga dapat membantu peserta didik meningkatkan pemahaman, menyajikan data dengan menarik dan terpercaya, memudahkan penafsiran data, dan mendapatkan informasi”.

Salah satu media pembelajaran yang dikembangkan adalah media cerita daerah. Banyak keunggulan media cerita daerah ini dibandingkan dengan media lainnya. Media pembelajaran media cerita daerah ini jumlahnya tidak begitu banyak dibandingkan dengan media lainnya, hal ini dikarenakan memang masih belum banyaknya lembaga-lembaga pendidikan yang memberikan perhatian untuk mengembangkan media ini serta keterbatasan kemampuan guru PKn pada informasi turut memberikan kontribusi minimnya media ini. Padahal kebutuhan akan media ini pada pembelajaran PKn sangatlah tinggi.

Dapatlah kita ketahui bahwa media pembelajaran contohnya media cerita daerah sangat penting dalam pembelajaran khususnya 
PKn. Untuk itu dengan menggunakan media ini diharapkan karakter peserta didik menjadi meningkat. Hal ini sangatlah sejalan dengan permasalahan kondisi pembelajaran PKn di SMPN 1 Kersamanah Garut, diharapkan peserta didik memiliki pengetahuan dan pemahaman mengenai cerita daerah yang disajikan dalam media, sehingga peserta didik dapat dengan mudah menghubungkan materi dalam kehidupan nyata yang lebih bermakna berdasarkan pengalamannya. Peserta didik dapat paham akan nilai-nilai karakter yang terkandung dalam cerita daerah dengan menggunakan model VCT.

Untuk itu peneliti mencoba melalui inovasi pembelajaran dengan menggunakan media cerita daerah ini, yang diharapkan dapat meningkatkan karakter peserta didik pada pelajaran PKn. Reformasi pembelajaran melalui media cerita daerah pada hakekatnya ingin memperbaiki cara belajar agar anak didik lebih cerdas, kritis, dan lebih bijaksana dalam berpikir dan bertindak. Melalui model VCT media pembelajaran cerita daerah diharapkan mata pelajaran PKn menjadi mata pelajaran yang powerfull serta bermakna bagi peserta didik.

Berdasarkan uraian di atas maka peneliti mengadakan penelitian untuk dapat menggambarkan penerapan model VCT menggunakan media cerita daerah dalam pembelajaran PKn untuk meningkatkan karakter peserta didik di SMP Negeri 1 Kersamanah Garut.

\section{METODE PENELITIAN}

Pendekatan penelitian menggunakan Penelitian Tindakan Kelas (Classroom Action Research) yang merupakan bagian dari tradisi penelitian kualitatif. Teknik pengumpulan data digunakan observasi, wawancara, evaluasi hasil belajar, dan dokumentasi yang hasilnya dikerjakan dalam bentuk catatan lapangan.

\section{HASIL DAN PEMBAHASAN}

Mengacu pada hasil temuan di lapangan pembentukan karakter peserta didik dengan model pembelajaran PKn VCT dengan menggunakan media cerita daerah meliputi tahap perencanaan pembelajaran, pelaksanaan pembelajaran, merefleksikan, dan evaluasi.

\section{Perencanaan model pembelajaran PKn model VCT dengan menggunakan media cerita daerah}

Berdasarkan wawancara menurut IP, pada langkah ini guru sebagai pengajar mampu merespon penggunaan model tersebut dengan menyiapkan rencana strategis berupa pembuatan perangkat pembelajaran yang didalamnya meliputi silabus dan RPP. Penyiapan perangkat pembelajaran yang merupakan sebuah instrumen yang memungkinkan guru untuk turut andil dalam mengambil peran penting dalam merumuskan pokok-pokok materi pembelajaran PKn. Tentu hal semacam ini memerlukan kesungguhan dan persiapan khusus dari guru. Perencanaan pembelajaran PKn dengan menggunakan model VCT disesuaikan dengan tuntutan dan kebutuhan pembelajaran baik mengenai bahan ajar, metode pembelajaran, tujuan pembelajaran termasuk didalamnya menganalisis dan mendeskripsikan kondisi peserta didik yang perlu ditanamkan nilai-nilai karakter yang baik dan positif, sehingga dengan itu guru merasa memiliki perhatian serius dalam mengajar dan mendidik peserta didik. Perencanaan pembelajaran PKn model VCT adalah langkah tepat dalam mewujudkan kualitas proses belajar mengajar di kelas.

Rencana tindakan antara lain merencanakan peningkatan karakter pembelajaran PKn melalui penerapan model VCT dengan menggunakan media cerita daerah akan dilaksanakan dengan Penelitian Tindakan Kelas yang terbagi kedalam tiga siklus, setiap siklus dibagi ke dalam beberapa kali tindakan. Rincian siklus dan tindakan yang akan dilaksanakan adalah sebagai berikut.

Siklus I. Dilaksanakan untuk melihat ketercapaian karakter dalam berupa aspek 
merujuk pada Kementerian Pendidikan Nasional Direktorat Pembinaan SMP 2011 terhadap kajian model VCT dengan menggunakan media cerita daerah. Untuk mencapai tujuan yang diharapkan dilaksanakan tindakan berikut: a) Tindakan ke-1, dilaksanakan pada hari Rabu, 11 Maret 2015; b) Tindakan ke-2, dilaksanakan pada hari Rabu, 18 Maret 2015. Indikator keberhasilan siklus I adalah pengetahuan peserta didik terhadap cerita daerah yang dijadikan sebagai materi pelajaran PKn. Indikator yang digunakan berdasarkan pada instrumen yang telah dirancang untuk meningkatkan karakter peserta didik. Perhatian dan kepedulian peserta didik terhadap pelajaran PKn atau pembelajaran mengenai peningkatan karakter peserta didik.

Siklus II. Dilaksanakan untuk peningkatan karakter peserta didik, pada tahap ini peserta didik melaksanakan tindakan yang dapat dijadikan sebagai aplikasi dari karakter yang telah di tanamkan pada tahapan sebelumnya: a) Tindakan ke-3, dilaksanakan pada hari Kamis, 26 Maret 2015; b) Tindakan ke-4, dilaksanakan pada hari Rabu, 8 April 2015. Tindakan yang dilakukan oleh peserta didik diukur dengan pembelajaran berbuat dan menganalisis media cerita daerah karakter yang terkandung dalam cerita tersebut menghayati, menganalisis Cerita Daerah Garut untuk mengetahui karakter yang bisa diteladani atau dicontoh.

Siklus III. Dilaksanakan untuk peningkatan karakter peserta didik dengan menganalisis video dan gambar agar memiliki kemampuan memecahkan masalah dan bisa menempatkan diri dalam posisi apapun. Pada akhirnya peserta didik dapat menarik kesimpulan. Adapun tindakannya: a) Tindakan ke-5, dilaksanakan pada hari Rabu, 15 April 2015; b) Tindakan ke-6, dilaksanakan pada hari Rabu, 22 April 2015; c) Tindakan ke-7, dilaksanakan pada hari Rabu, 29 April 2015.

Rencana berikutnya adalah menyusun Rencana Pelaksanaan Pembelajaran (RPP) dan melaksanakan skenario pembelajaran sesuai dengan rencana yang disusun bersama guru mitra yang diuraikan dalam RPP, Menetapkan media pembelajaran yaitu cerita daerah dan pengembangannya. Menetapkan tujuan yang ingin dicapai sebagai bahan penilaian, analisis dan refleksi. Tujuan yang ingin dicapai dari pembelajaran dengan penerapan model VCT dengan menggunakan media cerita daerah adalah agar peserta didik memiliki karakter baik, mampu mengenal cerita daerah, mengetahui karakter yang terkandung di dalam isi cerita daerah, dan dapat dijadikan teladan dalam kehidupan sehari-hari. Menetapkan indikator-indikator yang dapat dikembangkan sebagai alat ukur untuk menilai keberhasilan dalam peraihan karakter yang meliputi komponen-komponen karakter yang baik dengan merujuk pada karakter Cerita Daerah Garut sebagai bahan penilaian yakni religiusitas, kejujuran, kecerdasan, ketangguhan, kepedulian, demokrasi. Membagi dan menetapkan jumlah kelompok yang akan dibentuk secara demokrasi. Dan menyusun format penilaian baik lembar kerja peserta didik, penilaian proses dan hasil diskusi peserta didik serta penilaian unjuk kerja.

\section{Pelaksanaan atau implementasi model VCT dengan menggunakan media cerita daerah}

Menurut IP pelaksanaan model VCT pada siswa kelas VIII-F SMP Negeri 1 Kersamanah dilakukan sebagai upaya untuk memberikan pencerahan dan perbaikan terhadap kualitas proses belajar mengajar, yang diharuskan terciptanya indikator pembelajaran yang menyenangkan, efektif dan inovatif serta dapat merangsang lahirnya interaksi yang baik antara guru dan peserta didik.

Pelaksanaan pembelajaran PKn model VCT adalah tanggung jawab guru sebagai fasilitator untuk melaksanakan hal-hal yang berkaitan dengan kebutuhan belajar mengajar termasuk didalamnya menyiapkan bahan-bahan mengajar yang diperlukan. Langkah tersebut 
merupakan tuntutan yang harus direspon guru dalam menjawab kebekuan yang terjadi dalam pelaksanaan pembelajaran di kelas berupa lemahnya kedisiplinan peserta didik dalam memahami materi. Pelaksanaan model pembelajaran PKn didalamnya dilakukan mulai dari tahapan penjajakan materi, kesiapan guru dalam menerapkan model maupun kesiapan peserta didik dalam melaksanakan model tersebut.

Merefleksikan pembelajaran dalam pelaksanaan model VCT untuk meningkatkan karakter peserta didik di kelas VIII-F SMP Negeri 1 Kersamanah.

Berdasarkan wawancara dan observasi dalam penelitian ini peneliti merasa kesulitan dalam menyesuaikan materi yang akan dijadikan bahan ajar untuk media cerita daerah, materi yang harus disampaikan harus sesuai dengan kemampuan peserta didik yang dimiliki. Sulitnya memberikan motivasi kepada peserta didik untuk belajar aktif dengan menumbuhkan rasa percaya diri dan menghilangkan rasa malumalu ketika menjelaskan atau mempresentasikan media cerita daerah di depan kelas.

Hambatan yang terjadi pada saat pelaksanaan penelitian dapat diatasi dengan upaya-upaya perbaikan, yakni peneliti harus berusaha mencari dan menyesuaikan materi yang akan dijadikan bahan ajar dalam media cerita daerah yang sesuai dengan kemampuan peserta didik, sehingga mudah dipahami oleh peserta didik, peserta didik menjadi lebih bersemangat dan antusias dalam proses pembelajaran, sehingga pembelajaran menjadi menarik. Peneliti harus memotivasi peserta didik agar memiliki sikap percaya diri sehingga peserta didik menjadi lebih berani berbicara di depan kelas. Peneliti juga harus membuat suasana kelas yang nyaman dengan memberikan motivasi kepada peserta didik dan mengembangkan keterampilan peserta didik sehingga mendapatkan hasil belajar yang diharapkan.

\section{Pembentukan karakter peserta didik melalui pembelajaran PKn model VCT dengan menggunakan media cerita daerah}

Berdasarkan observasi perubahan yang signifikan dalam diri peserta didik yakni pada saat guru menyampaikan salam dihadapan peserta didik, peserta didik merasa termotivasi untuk ikut mengambil bagian dalam menyampaikan salam tersebut baik pada saat dia berada di kelas maupun pada saat bermain di halaman sekolah. Kondisi semacam ini mengharuskan kepada guru dan seluruh komponen sekolah harus sinergis dalam mendidik peserta didik agar mereka ini tumbuh menjadi generasi soleh atau solehah yang memiliki kepribadian yang dapat dijadikan panutan oleh orang yang ada disekitarnya baik di lingkungan sekolah, keluarga maupun dalam lingkungan masyarakat. Tiga lingkungan yang ada merupakan bagian penting dalam menanamkan pondasi karakter yang baik.

Sekolah SMP Negeri 1 Kersamanah merupakan salah satu sekolah negeri yang didalamnya serat dengan pembinaan nilai-nilai keagamaan, tentu hal yang demikian diperlukan teladan yang baik dari seorang guru pada saat mereka ini mengajarkan akhlak atau karakter dihadapan peserta didik, sehingga pembinaan tersebut tidak interferstasikan negatif oleh peserta didik sendiri. Oleh karena itu kondisi sekolah yang ideal dan dikatakan berkualitas adalah sekolah yang mampu menciptakan tunas generasi bangsa yang beriman dan bertakwa kepada Allah, berakhlak mulai, serta mempunyai jiwa kemandirian. Dengan demikian dalam membangun moralitas bangsa dan negara ini adalah terletak dari kemantangan jiwa atau kepribadian manusianya. Indikator tersebut merupakan ukuran dan barometer utama dalam menciptakan lingkungan masyarakat yang humanis terjalin ukuwah persaudaraan serta menghindari diri dari sikap desintegrasi/ perpecahan. Dengan demikian proses belajar mengajar yang dilakukan di kelas sangat 
penting diajarkan konsep penanaman nilai-nilai karakter.

Model pembelajaran VCT sangat tepat dan mendapatkan respon yang baik di hadapan peserta didik di sekolah SMP Negeri 1 Kersamanah maupun di dewan guru. Indikator keberhasilan pencapaian pelaksanaan model pembelajaran PKn model pembelajaran VCT maupun di dewan guru. Indikator keberhasilan pencapaian pelaksanaan model pembelajaran PKn VCT telah melahirkan nilai karakter positif baik nilai religius, jujur, kecerdasan, ketangguhan, kepedulian, demokrasi. Nilai tersebut terakumulasi secara langsung dalam nilai-nilai yang berubungan dengan Allah SWT, nilai yang berhubungan dengan diri sendiri, nilai yang berhubungan dengan sesama, dan nilai yang berhubungan dengan bangsa dan negara. Tentu nilai yang telah dijabarkan secara spesifikasi diatas adalah modal dasar bagi terbentuknya generasi emas yang berkualitas.

Berdasarkan hasil temuan di lapangan selama penelitian berlangsung, dapat diketahui bahwa penerapan model VCT dengan menggunakan media cerita daerah untuk meningkatkan karakter peserta didik dalam pembelajaran PKn ini dapat dijadikan sebagai alternatif yang digunakan untuk meningkatkan karakter peserta didik. Berdasarkan penelitian yang telah dilaksanakan bahwa peningkatan karakter peserta didik di kelas VIII-F mengalami peningkatan yang signifikan. Hal tersebut dapat dilihat pada analisis sebagai berikut.

\section{Mendesain pembelajaran PKn melalui penerapan model VCT dengan menggunakan media cerita daerah untuk meningkatkan karakter peserta didik}

Perencanaan yang dilakukan peneliti adalah melakukan diskusi dengan guru pelajaran PKn dan guru mitra sebagai upaya menyusun langkah yang benar dan sesuai dengan pembelajaran yang sedang berlangsung, karena pada dasarnya materi yang berlangsung harus sesuai dengan tujuan yang diinginkan peneliti. Hal tersebut berdasar temuan permasalahan di lapangan dan karena itu peneliti bersama guru mitra merencanakan pembelajaran yang mampu menyelesaikan permasalahan tersebut.

Pembelajaran menggunakan model VCT mendorong peserta didik untuk belajar menganalisis dan karakter baik karena pada dasarnya model ini mampu mengembangkan potensi afektual peserta didik serta mengintegrasikan dengan potensi kognitif dan psikomotorik maupun potensi eksternal lainnya.

Proses pembelajaran VCT merupakan sebuah model pembelajaran yang mampu melibatkan peserta didik secara aktif dalam proses pembelajaran. Pembelajaran VCT melibatkan peserta didik, mengajarkan untuk mengembangkan pembinaan moral, dan peserta didik dapat mengklarifikasi nilai moral yang ada dalam kehidupan. Pada saat pembelajaran terjadi suatu komunikasi dua arah yang dapat dilakukan dalam bentuk tanya jawab atau diskusi, disini sangat dibutuhkan peran aktif dari guru yang bersangkutan, akan tetapi guru bukan menjadi teaching center akan tetapi guru berperan sebagai fasilitator dan motivator yang selalu memberikan kesempatan kepada peserta didik untuk berpartisipasi, mengembangkan kemampuan serta keberanian dalam mengemukakan pendapat, dengan demikian akan tercipta proses pembelajaran yang interaktif dalam kegiatan belajar mengajar di kelas.

Dengan demikian, pembelajaran VCT dapat mengembangkan kepribadian peserta didik melalui nilai dan moral sehingga dapat memberikan pengalaman belajar sebagai motivasi untuk memiliki nilai-nilai karakter yang dapat meningkatkan kualitas diri sebagai manusia yang berkarakter.

Penelitian model VCT ini dengan menggunakan media pembelajaran yaitu media Cerita Daerah Garut karena pada dasarnya media pembelajaran untuk mempermudah peserta didik dalam proses belajar mengajar. 
Hal ini sependapat dengan Hamalik (1994) dalam suatu proses belajar mengajar, dua unsur penting adalah model mengajar dan media pembelajaran mengemukakan bahwa:

Pemakaian media pembelajaran dalam proses belajar mengajar dapat membangkitkan keinginan dan minat yang baru, membangkitkan motivasi dan rangsangan kegiatan belajar dan bahkan membawa pengaruh-pengaruh psikologis terhadap peserta didik.

Dalam penelitian ini peneliti dan guru mitra merencanakan akan menggunakan media Cerita Daerah Garut yaitu cerita asal mula situ bagendit, asal mula nama dayeuh manggung, prabu kiansantang, asal nama garut, cerita babad limbangan, prabu siliwangi.

Dengan demikian potensi dalam mengembangkan konsep pembelajaran pada dasarnya mentransformasikan nilai-nilai pembelajaran tersebut sebagai upaya untuk membentuk kepribadian yang baik. Urgensi perencanaan pembelajaran mengajarkan kepada guru dan peserta didik untuk bekerja sama, berkomunikasi, berdiskusi untuk menyampaikan pikiran atau ide gagasan dalam menjelaskan materi yang akan diajarkan, karena hal demikian merupakan komponen penting dalam pendidikan karakter yang dapat diinternalisasikan dalam pendidikan formal di sekolah.

Menurut Abidin (2012, hlm. 40) dapat dilakukan dalam menginternalisasikan pendidikan karakter dalam pembelajaran adalah melalui pengembangan model-model pembelajaran berbasis karakter. Istilah pengembangan dalam hal ini bukan hanya berarti penciptaan model melainkan juga pemanfaatan model yang telah ada sebagai saluran pendidikan karakter. Dengan demikian internalisasi pendidikan karakter ke dalam pembelajaran melalui model pembelajaran dapat dilakukan dengan menggunakan model pembelajaran yang telah ada, namun juga bisa melalui model pembelajaran baru yang sengaja dikembangkan untuk keperluan tersebut.
Merujuk pada gagasan di atas bahwa perencanaan pembelajaran dipandang penting dalam menerapkan model di kelas, sehingga dengan itu guru merasa terlatih dan berkomitmen untuk menjelaskan isi pembelajaran tersebut berdasarkan prosedur/ketentuan yang ada dalam rencana pembelajaran yang ada dalam silabus dan RPP. Menurut Knirk \& Gustafson (1986, hlm. 18) "pembelajaran merupakan suatu proses yang sistematis melalui tahap rancangan, pelaksanaan, dan evaluasi. Pembelajaran tidak terjadi seketika, melainkan sudah melalui tahap perancangan pembelajaran". Selanjutnya Knirk \& Gustafson (1986, hlm. 18) mengemukakan pembelajaran melibatkan tiga komponen utama yang saling berinteraksi yaitu guru (pendidik), siswa (peserta didik), dan kurikulum. Komponen tersebut melengkapi struktur dan lingkungan belajar formal. Hal ini menggambarkan bahwa interaksi pendidik dengan peserta didik merupakan inti proses pembelajaran (instructional). Dengan demikian bahwa peran guru sangat diharapkan dalam mengintegrasikan pembelajaran model VCT dengan menggunakan media cerita daerah yang dapat menumbuhkan karakter peserta didik dalam setiap kegiatan proses belajar di kelas. Karena itu, disadari sungguh guru adalah sosok manusia yang mempunyai karakteristik berbeda dengan masyarakat lainnya. Perbedaan tersebut disadari oleh adanya faktor internal dalam diri yakni tanggung jawab dalam mendidik generasi bangsa.

Perencanaan pembelajaran dan strategi yang baik untuk menumbuhkan minat peserta didik dalam menggali informasi yang berkenaan dengan apa yang disampaikan oleh guru. Oleh sebab itu untuk membentuk kualitas sumber daya manusia yang unggul dalam intelektual dan memiliki kepribadian yang baik muatan utamanya perlu adanya komitmen yang kuat dari seorang pendidik tersebut, sehingga sekolah tidak hanya dijadikan sebagai tempat menerima 
peserta didik akan tetapi sekolah sebagai sarana pembentukan pengetahuan, sikap dan keterampilan. Dari indikator ini peserta didik juga selain sebagai murid di kelas, tetapi peserta didik juga bertindak sebagai pelopor dan pembaharuan dalam menciptakan lingkungan yang kondusif baik di sekolah, keluarga, masyarakat dengan menampilkan sikap dan perilaku yang positif.

Dengan demikian bahwa konsep pembelajaran PKn dengan model VCT tepat dalam mengintegrasikannya di dalam pembentukan karakter peserta didik. Kenapa hal itu penting, karena dalam pembelajaran yang menggunakan model VCT peserta didik dilatih untuk bagaimana menganalisis karakter yang terkandung didalam media cerita daerah. Manfaat model tersebut adalah terbangunnya nilai-nilai karakter religiusitas, jujur, kecerdasan, ketangguhan, kepedulian, demokrasi.

Nilai-nilai terkandung dalam model VCT bagian dari aplikasi nilai-nilai karakter yang harus direspon oleh guru dan peserta didik dengan sebaik mungkin. Berdasarkan pengamatan awal bahwa konsep pembelajaran yang ada pada sekolah SMP Negeri 1 Kersamanah merupakan salah satu sekolah yang mayoritas peserta didiknya mempunyai karakter yang berbeda-beda dalam materi maupun dalam perilaku sehingga kondisi tersebut sangat diperlukan upaya kongkrit dalam pengintegrasian model pembelajaran PKn.

Dengan demikian rancangan pembelajaran PKn dalam menerapkan model VCT sangat penting diajarkan dalam lingkungan sekolah. Sebab dengan itu diharapkan peserta didik dapat berpartisipasi aktif dalam pembelajaran di kelas. Sifat demikian merupakan unsur penanaman nilai-nilai karakter. Menurut Budimansyah (2012, hlm.21) dalam kegiatan belajar mengajar dikelas pengembangan nilai-karakter dilaksanakan dengan menggunakan pendekatan terintegrasi dalam semua mata pelajaran (embedded approach).
Selain apa yang telah diuraikan sebelumnya berkaitan dengan perencanaan pembelajaran PKn model VCT dimana peneliti membangun komunikasi yang intensif dengan guru mitra terkait dengan pola pembelajaran yang pernah diterapkan sebelumnya. Menurut argumentasi yang disampaikan oleh guru mitra bahwa konsep pembelajaran PKn yang biasanya adalah konsep pembelajaran yang sifatnya konvensional.

Dimana pembelajaran tersebut yang memiliki peran yang sangat besar dan dominan adalah seorang guru sedangkan peserta didik hanya siap dan menerima materi apa yang disampaikan oleh guru dimaksud sehingga kondisi pembelajaran seperti ini peserta didik merasa sangat lemah dan mengasah kemampuan intelektualnya artinya bahwa pembelajaran konvensional sejatinya biasa mengasah bagaimana peserta didik dengan temuan lainnya biasa menganalisis yang terkandung di dalam cerita daerah. Guru sebisa mungkin membangun pola pembelajaran dalam pendidikan khususnya di sekolah untuk bisa memecahkan kebekuan dalam proses belajar mengajar di kelas.

\section{Melaksanakan pembelajaran pendidikan kewarganegaraan melalui penerapan model VCT (Value Clarification Technique) dengan menggunakan media cerita daerah untuk meningkatkan karakter peserta didik}

Pelaksanaan proses belajar mengajar dalam pembelajaran PKn dengan model VCT pada hakikatnya adalah untuk menganalisis nilai, mengklarifikasi nilai, moral, norma keyakinan prinsip baik berdasarkan norma umum, karena disadari bahwa hampir sebagian besar pelaksanaan model VCT ini peserta didik merasa antusias dan semangat dalam mengerjakannya, walaupun sebagian kecil peserta didik lemah dalam mengintegrasikan model VCT ini dalam mengerjakan tugas yang diberikan. Hal ini senada dengan Djahiri (1985, hlm. 64) pola pembelajaran VCT dianggap unggul untuk pembelajaran afektif karena: 
a. Mampu membina dan mempribadikan nilai dan moral.

b. Mampu mengklarifikasi dan mengungkapkan isi pesan materi yang disampaikan.

c. Mampu mengklarifikasi dan menilai kualitas nilai moral diri peserta didik dan nilai moral dalam kehidupan nyata.

d. Mampu mengundang, melibatkan, membina dan mengembangkan potensi diri peserta didik terutama potensi afektualnya.

e. Mampu memberikan pengalaman belajar dalam berbagai kehidupan.

f. Mampu menangkal, meniadakan mengintervensi, dan menyubversi berbagai nilai moral naif yang ada dalam sistem nilai dan moral yang ada dalam diri seseorang.

g. Menuntun dan memotivasi untuk hidup layak dan bermoral tinggi.

Pembelajaran VCT dapat mengembangkan kepribadian peserta didik melalui nilai dan moral sehingga dapat memberikan pengalaman belajar sebagai motivasi untuk memiliki nilainilai karakter yang dapat meningkatkan kualitas diri sebagai manusia yang berkarakter.

Sebelum model ini diterapkan di kelas peneliti mencoba menyakinkan kepada guru mitra bahwa model yang dilakukan dalam pembelajaran PKn adalah model yang berbasis nilai karakter yang bisa melatih kecerdasan peserta didik untuk mengembangkan kemampuan sumber daya manusianya dalam hal ini kemampuan untuk mengerjakan sesuatu yaitu menganalisis nilai yang terkandung dalam media cerita daerah. Dari penjelasan itu guru mitra sepakat menerapkan model tersebut. Tentu penerapan model yang ada dalam hal ini model VCT disesuaikan dengan materi yang diajarkan oleh guru di kelas. Materi pembelajaran PKn pada kelas VIII-F adalah materi yang sifatnya analisis dan perlu penjelasan menarik agar peserta didik memahami dan menghayati dari apa yang terkandung dalam pembelajaran khususnya terhadap media cerita Daerah Garut.
Dari gambaran di atas jelas bahwa VCT disamping membawakan the intende mean and values (isi pesan keharusan yang normatif idiil) juga mendukungnya secara kukuh (terpadu melalui media stimulusnya) dan kondisional fungsional.

Berdasarkan pernyataan di atas, dapat disimpulkan bahwa VCT dimaksudkan untuk melatih dan membina peserta didik tentang bagaimana cara menilai, mengambil keputusan terhadap suatu nilai umum.

Pembelajaran VCT dapat mengembangkan kepribadian peserta didik melalui nilai dan moral sehingga dapat memberikan pengalaman belajar sebagai motivasi untuk memiliki nilainilai karakter yang dapat meningkatkan kualitas diri sebagai manusia yang berkarakter.

Karena itu, guru sebagai pengajar mencoba memberikan perhatian dan pandangan kongkrit kepada peserta didik terkait pelaksanaan model VCT. Implikasi dari pelaksanaan model merupakan komponen penting dalam pendidikan karakter sebagaimana dikemukakan Menurut Burke (dalam Samani \& Hariyanto, 2012, hlm. 43) pendidikan karakter semata-mata merupakan bagian dari pembelajaran yang baik dan merupakan bagian yang fundemantal dari pendidikan yang baik.

Mata pelajaran PKn salah satu bagian unsur penting dalam pendidikan karakter di sekolah. Untuk menjajaki konsep yang demikian berkenaan dengan pengintegrasian model VCT maka langkah yang harus ditempuh oleh guru adalah mengarahkan peserta didik untuk memperhatikan segala apa-apa yang berkenaan dengan model VCT. Penjelasan itu dimaksudkan yakni guru mencoba membantu peserta didik menganalisis karakter yang terkandung didalam cerita daerah.

Setelah masalah tersebut disepakati oleh peserta didik, tindak lanjutnya yakni membagi peserta didik dalam beberapa kelompok yang terdiri dari enam kelompok. Masing-masing kelompok bertanggung jawab terhadap tugas 
yang diberikan dengan beberapa media cerita daerah yaitu asal mula situ bagendit, asal mula nama dayeuh manggung, prabu kiansantang, asal nama garut, cerita babad limbangan, prabu siliwangi. Artinya kelompok yang telah dibagi berhak menganalisis isi cerita daerah yang sudah di bagikan, masing-masing kelompok menganalisis karakter yang terkandung di dalam isi cerita daerah tersebut.

Media cerita yang dimaksudkan adalah unsur penting dalam menggali pengetahuan yang dapat dijadikan rujukan dalam mengintegrasikan karakter dalam mata pelajaran, karena hal tersebut merupakan salah satu tujuan pendidikan karakter yang harus dibangun. Mulyasa (2012, hlm. 9) pendidikan karakter bertujuan untuk meningkatkan mutu proses dan hasil pendidikan yang mengarah pada pembentukan karakter dan akhlak mulia peserta didik secara utuh, terpadu, dan seimbang.

Setelah itu guru mengarahkan peserta didik untuk menganalisis karakter yang terkandung di dalam isi Cerita Daerah Garut. Dari keenam kelompok yang telah memiliki masing-masing cerita daerah yang dianalisis. Setelah peserta didik selesai menganalisis cerita daerah masing-masing, kemudian mempresentasikannya di depan kelas.

Pelaksanaan model VCT memiliki dampak positif dimana peserta didik turut andil dalam menganalisis karakter yang terkandung di dalam media cerita daerah. Disisi lain pembentukan karakter peserta didik diharapkan dapat menjadi ukuran dan barometer dalam mewujudkan peserta didik yang berakhlak mulia. Tentu pembentukan karakter tersebut dimaksudkan untuk memberikan pembinaan diri terhadap fungsi dan peran peserta didik sebagai warga belajar di sekolah. Pendidikan karakter pada tingkat satuan pendidikan mengarah pada pembentukkan budaya sekolah, yaitu nilai-nilai yang melandasi perilaku, tradisi, kebiasaan sehari-hari, serta simbol-simbol yang dipraktikkan oleh semua warga sekolah, dan masyarakat sekitarnya. Budaya sekolah merupakan ciri khas, karakter atau watak, dan citra sekolah tersebut di mata masyarakat luas.

Dengan demikian konsep nilai karakter yang terintegrasi dalam model pembelajaran PKn VCT sebagaimana yang telah diuraikan sebelumnya memiliki manfaat yang positif. Selain manfaat dari sisi pengetahuan juga sangat berguna bagi pembentukan sikap atau karakter. Oleh karena itu peserta didik sebagai warga sekolah dan warga negara diharapkan dapat bekerja keras, berakhlak mulia, kreatif, bekerja sama dalam mewujudkan manusia pembangunan yang beriman dan bertakwa kepada Allah karena hal ini merupakan tujuan dari esensi pendidikan itu sendiri. Sebagaimana tertuang dalam UU NO. 20 Tahun 2003 Tentang Sistem Pendidikan Nasional Pasal 1 bahwa:

Pendidikan adalah usaha sadar dan terencana untuk mewujudkan suasana belajar dan proses pembelajaran agar peserta didik secara aktif mengembangkan potensi dirinya untuk memiliki kekuatan spiritual keagamaan, pengendalian diri, kepribadian, kecerdasan, akhlak mulia, serta keterampilan yang diperlukan dirinya, masyarakat, bangsa, dan negara.

Dari uraian yang terkandung dalam penjelasan UU di atas kiranya langkah yang paling tepat dalam mewujudkan keagaman yang muatan dasarnya adalah bagaimana anak diajarkan untuk mengetahui posisi dan kedudukan dia disisi Allah, sebab dengan itu peserta didik mampu untuk menginternalisasikan nilai karakter yang terkandung dalam ajaran agama islam dijadikan ukuran dasar dalam membangun hubungan baik secara vertikal dengan Allah melalui gerakan-gerakan seperti peserta didik dibiasakan solat, membaca alquran dan amalan lainnya yang berkenaan dengan kewajiban terhadap Allah sehingga nilai-nilai yang telah dijalankan oleh peserta didik tersebut bisa mempengaruhi mentalnya menjadi generasi yang soleh dan solehah. 
Dari gambaran yang telah diuraikan di atas dapat dipahami bahwa internalisasi pendidikan karakter dalam pembelajaran PKn yang diajarkan pada sekolah SMP Negeri 1 Kersamanah pada prinsipnya mengajarkan kepada peserta didik untuk giat belajar serta bisa menunjukkan kemampuan akhlak yang mulia dihadapan guru maupun sesama teman baik di kelas maupun di luar kelas. Sehingga indikator pembelajaran yang berkaitan dengan menganalisis cerita daerah dinyatakan dengan sikap dan tindakan yang terpuji. Oleh sebab itu perhatian guru dan pihak sekolah merupakan potret yang ideal dalam menumbuh kembangkan sebuah peradaban bangsa yang berkualitas.

\section{Merefleksikan pembelajaran pendidikan kewarganegaraan melalui penerapan model VCT dengan menggunakan media cerita daerah untuk meningkatkan karakter peserta didik}

Penelitian ini tentunya tidak terlepas dari hambatan-hambatan yang dialami peneliti bersama guru mitra. Kendala-kendala yang dihadapi saat penelitian adalah sulitnya menyesuaikan materi yang akan dijadikan dengan Media Cerita Garut, materi yang disampaikan harus sesuai, namun dengan seringnya berdiskusi bersama mitra peneliti dan guru mata pelajaran PKn, kendala yang tadinya sulitpun sedikit menipis dan dapat terselesaikan dengan baik.

Selain itu peserta didik harus selalu dibimbing oleh guru atau peneliti, agar penerapan model VCT dengan menggunakan media cerita daerah dapat terarah dan terfokus saat dilaksanakan.

Pembelajaran ini pula, peneliti merasa kesulitan karena dituntut harus bisa mendorong, memberikan motivasi kepada peserta didik yang pasif untuk menjadi aktif dalam belajar. Selain itu peserta didik dituntut harus bisa menganalisis cerita yang terkandung di dalam cerita daerah. Menurut Djahiri (1992, hlm. 64), yaitu:
Mengklarifikasi nilai dan moralita dan norma keyakinan/prinsip baik berdasarkan norma umum (etika, estetika, logika/ilmu, agama, budaya dan hukum positif) maupun yang ada atau mempribadi dalam diri ataupun kehidupannya. Dengan mencoba menerapkan model VCT dengan menggunakan media cerita daerah untuk meningkatkan karakter peserta didik di kelas VIII-F berhasil dilakukan dengan baik. Karena pada hakikatnya model VCT merupakan tindakan mengklarifikasi nilai.

Selain itu kendala-kendala yang ditemukan dalam pembelajaran, peneliti dihadapkan pada beberapa tantangan dan kendala yang muncul dapat terselesaikan dengan baik. Beberapa kendala yang ditemukan selama penelitian dilaksanakan antara lain: a. Kendala berkaitan dengan alokasi waktu pembelajaran. b. Kendala dapat meningkatkan aktivitas, perhatian dan antusiasme peserta didik dalam mengikuti pembelajaran. Hal ini muncul karena mereka terbiasa dengan penggunaan pendekatan pembelajaran yang hanya menuntut kemampuan kognitif bahkan terbatas pada knowledge (C1) saja dan kurang menggali kemampuan sisi afektif dan psikomotor. c. Kendala yang berkaitan dengan penilaian dalam megukur ketercapaian peningkatan karakter.

VCT adalah salah satu model pendekatan yang mampu mengundang, melibatkan atau menggetarkan, melakonkan serta membina, meningkatkan dan mengembangkan potensi afektual peserta didik serta menginteraksinya dengan potensi kognitif dan psikomotorik maupun dengan potensi eksternal lainnya (peserta didik lain maupun lingkungan belajarnya). "VCT adalah model pengajaran yang bisa dilaksanakan dengan utuh dan baik akan mampu menggerakan "pagelaran multi domain" taksonomik tinggi dan multidimensional" (Djahiri, 1992, hlm. 47-49).

Dengan sering dilakukannya diskusi bersama guru mitra dan pihak-pihak lain yang lebih berpengalaman, dan dengan usaha peneliti 
mencari sumber referensi kemudian mendapatkan solusi untuk memecahkan permasalahan tersebut, kendala-kendala yang tadinya dirasakan sulit menjadi mudah diselesaikan. Peneliti melakukan perbaikan-perbaikan menunjang peningkatan karakter peserta didik lebih baik dan sesuai dengan tujuan penelitian.

\section{Karakter peserta didik di kelas VIII-F SMP Negeri 1 Kersamanah Garut setelah melaksanakan pembelajaran PKn melalui model VCT dengan menggunakan cerita daerah}

Berdasarkan hasil observasi langsung mengenai pembelajaran $\mathrm{PKn}$ dengan model VCT telah melahirkan perubahan perilaku yang konstruktif dan membangun. Dari pihak guru sendiri dimana model tersebut memiliki dampak signifikan diantaranya guru dengan mudah mengidentifikasi perilaku peserta didik di kelas dalam proses belajar mengajar. Perubahan itu dimaksudkan untuk memberikan gambaran terhadap pentingnya model pembelajaran model VCT. Dengan demikian untuk mewujudkan kualitas pendidikan yang bermutu, maka peran pendidik dalam hal ini guru harus mampu memberikan perubahan yang baik terhadap pembentukan karakter siswa karena dengan itu diharapkan generasi bangsa ini bisa menjadi manusia yang paripurna. Manusia yang mampu menampilkan sosok perubahan, tentu hal itu diperlukan yang baik dari pihak guru sendiri. Sehubungan itu, Johnson (2002, hlm. 63) mengemukakan kemampuan profesional yaitu : penguasaan pelajaran yang terkini atas penguasaan bahan yang harus diajarkan, dan konsepkonsep dasar keilmuan bahan yang diajarkan tersebut, penguasaan dan penghayatan atas landasan dan wawasan kependidikan dan keguruan, penguasaan proses-proses kependidikan, keguruan dan pembelajaran peserta didik.

Penjabaran nilai-nilai karakter berdasarkan observasi terhadap karakter peserta didik dalam pembelajaran $\mathrm{PKn}$ dengan penerapan model VCT sebagai berikut: a. Nilai karakter religius dan jujur merupakan nilai yang senantiasa dibangun dalam setiap aktifitas belajar di SMP Negeri 1 Kersamanah. Berdasarkan observasi lapangan dimana peserta didik telah menampilkan nilai keagamaan berupa peserta didik mengucapkan salam menampilkan perilaku kejujuran baik dalam bentuk ucapan dan perbuatan. Nilai religius peserta didik dilakukan pada saat masuk kelas, yakni membaca doa sebelum memulai pelajaran dan setelah selesai pelajaran. Hal itu peserta didik lakukan semata-mata untuk meningkatkan nilai keimanan dan ketakwaan kepada Allah. Dalam ajaran Islam sendiri sangat menganjurkan diajarkan nilai-nilai yang positif, karena hal itu bagian dari mengamalkan ajaran agama. b. Nilai kecerdasan. Nilai ini dilihat dari kemampuan peserta didik dalam menganalisis media cerita daerah, peserta didik harus cerdas bisa menganalisis karakter yang terkandung di dalam Cerita Daerah Garut. c. Nilai ketangguhan, merupakan nilai yang sangat penting untuk ditanamkan dalam proses belajar. Peserta didik telah menunjukkan nilai karakter yang ada, hal itu dapat diidentifikasi dari ketangguhan dalam mengerjakan tugas dan siswa telah berusaha mempresntasikan tugas menganalisis karakter media cerita daerah dengan ketangguhan dan sungguh-sungguh. d. Nilai kepedulian lingkungan dan kepedulian sosial. Nilai peduli lingkungan merupakan nilai yang sangat penting dilakukan. Peserta didik di SMP Negeri 1 Kersamanah telah menampilkan nilai tersebut disaat ada kegiatan proses belajar mengajar. Misalkan peserta didik membersihkan ruang belajar di kelas membuang sampah pada tempatnya, dan membersihkan halaman sekolah ketika kerja bakti sosial. Sedangkan nilai peduli sosial peserta didik membantu peserta didik lain ketika memerlukan bantuan. Misalkan peserta didik menolong teman kelas yang kesulitan dalam mengerjakan tugas maupun memberikan alat belajar berupa pulpen/pena untuk digunakan dalam menulis materi yang disampaikan oleh 
guru. e. Nilai Demokrasi. Nilai karakter yang demikian adalah nilai yang dilakukan peserta didik disaat proses belajar. Nilai demokrasi yang dibangun digunakan dalam kegiatan di kelas pada saat peserta didik mengusulkan padangan atau ide. Selain itu pembagian kelompok secara demokrasi, peserta didik memilih kelompoknya sendiri tidak ditentukan oleh guru.

\section{PENUTUP}

Model pembelajaran VCT sangat tepat dan Pada pembelajaran siklus I, II dan III mendapatkan respon yang baik oleh peserta didik di sekolah SMP 1 Kersamanah.

Kepada guru dan peserta didik agar membangun mitra kerja sama yang baik dalam penanaman nilai-nilai karakter dengan menerapkan model VCT sebagai model interaktif dalam proses belajar mengajar di kelas. Untuk mewujudkan hal yang demikian diperlukan sinergitas antara komponen sekolah.

\section{DAFTAR PUSTAKA}

\section{Buku:}

Abidin, Y. (2012). Pembelajaran Membaca Berbasis Pendidikan Karakter. Bandung: PT Refika Aditama.

Al Muchtar, S. (2008). Strategi Pembelajaran Pendidikan IPS. Bandung: SPS UPI.

Arsyad, A. (2011). Media Pembelajaran. Jakarta: PT Grafindo Persada.

Budimansyah, D. (2012). Penguatan Pendidikan Kewarganegaraan Untuk Membangun Karakter Bangsa. Bandung: Widya Aksara Press.

Darmadi, H. (2009). Dasar Pendidikan Moral, Landasan Konsep Dasar dan Implementasi. Bandung: Alfabeta.

Daryono. (2008). Pengantar Pendidikan Pancasila dan Kewarganegaraan. Jakarta: PT Rineka Cipta.

Djahiri, A Kosasih. (2006). Pendidikan Nilai Moral dalam Dimensi Pendidikan Kewarganegaraan: Menyambut 70 tahun Prof. Drs. H.A Kosasih Djahiri. Bandung: Laboratorium PKn FPIPS UPI.
Djahiri, K. (1985). Strategi Pengajaran Afektif Nilai Moral VCT dan Games dalam VCT. Bandung: Jurusan Pendidikan Moral dan Kewarganegaraan FPIPS IKIP.

Djahiri, K. (1992). Menelusuri Dunia Afektif Pendidikan Nilai dan Moral. Bandung: Lab PMPKN FPIPS IKIP Bandung.

Djahiri, K. (1992). Menelusuri Dunia Afektif Pendidikan Nilai dan Moral. Bandung: Lab PMPKN FPIPS IKIP Bandung.

Hamalik. (1994). Media Pembelajaran. Bandung: Citra Aditya Bakti.

Johnson, D. W. \& Johnson, R. T. (2002). Meaningful Assessment: A. Manageable and Cooperative Process. Boston: Allyn and Bacon publisher.

Knirk, F. G. dan Gustafon, K. L. (1986). Instructional Technology A Systematic Satuan Pendidikan SD, SMP dan SMA. Yogyakarta: Pustaka Yustisia.

Koesoma, D. (2009). Pendidikan Karakter Di Zaman Keblinger. Jakarta: PT Grasindo.

Komalasari, K. (2011). "Pendidikan Karakter di Persekolahan China Dalam Pendidikan Karakter: Nilai Inti Bagi Upaya Pembinaan Kepribadian Bangsa. Bandung Widya Aksara Press.

Mulyasa, E. (2012). Manajemen Pendidikan Karakter. Jakarta: Bumi Aksara.

Said, H. dkk. (2010, hlm. 9) Bahan Pelatihan Penguatan Metodologi Pembelajaran Berdasarkan Nilai Budaya Untuk Membentuk Daya Saing Dan Karakter Bangsa, Pengembangan Pendidikan Budaya Dan Karakter.

Samani, M. dan Hariyanto. (2012). Konsep dan Model Pendidikan Karakter. Bandung: Remaja Rosdakarya.

Sapriya. (2011). Pendidikan IPS Konsep dan Pembelajaran. Bandung: PT. Remaja Rosdakarya Offset.

Sugiyono. (2010). Metode Penelitian Kuantitatif Kualitatif dan $R \& D$. Bandung: Alfabeta.

Wahab, A. A. \& Sapriya. (2011). Teori dan Landasan PKn. Bandung: Alfabeta.

Winarno. (2013). Pembelajaran Pendidikan Kewarganegaraan: Isi, Strategi, dan Penilaian. Jakarta: Bumi Aksara.

Winataputra, U. S. \& Budimansyah, D. (2007). Civic Education: Konteks, Landasan, Bahan Ajar, dan Kultur Kelas. Bandung: 
Prodi Pendidikan Kewarganegaraan. SPs, Wiriaatmadja, R, (2009). Metode Penelitian UPI.

Undang-Undang Republik Indonesia Nomor 20

Tahun 2003 tentang Sistem Pendidikan Kelas, Untuk Meningkatkan Kinerja Guru Nasional. dan Dosen. Bandung: PT Remaja Rosda Karya. 
JPIS, Jurnal Pendidikan IImu Sosial, Vol. 25, No. 1, Edisi Juni 201657 